\title{
PENGARUH PERBANDINGAN KEDELAI DENGAN WIJEN SANGRAI GILING TERHADAP KADAR KALSIUM SUSU KEDELAI
}

\author{
Ambarwani $^{1}$ Pramudya Kurnia ${ }^{2}$ Fitriana Mustikaningrum ${ }^{2}$ \\ Mahasiswa S1 Gizi FIK UMS Jln A Yani Tromol Post 1 Kartasura1 \\ Dosen Gizi FIK UMS. Jln A Yani Tromol Post 1 Kartasura2,3 \\ Email : pk212@ums.ac.id² fitriana.mustikaningrum@ums.ac.id3
}

\begin{abstract}
Abstrak. Kekurangan kalsium dimasa remaja dan dewasa awal akan meningkatkan resiko osteoporosis. Prevalensi osteoporosis penduduk Indonesia tahun 2005 adalah 10,3\%, prevalensi osteopenia pada kaum muda (umur $<25$ tahun) adalah $37,1 \%$ dan pada wanita dewasa muda (umur 18 - 23 tahun) mencapai 39,5\%. Salah satu cara untuk mencegah terjadinya osteopenia dan osteoporosis adalah dengan mengkonsumsi susu sapi. Pemasalahannya susu sapi harganya mahal, sehingga salah satu alternatifnya adalah dengan mengkonsumsi susu kedelai. Susu kedelai mempunyai rasa dan bau yang langu serta kandungan kalsiumnya lebih rendah dari susu sapi. Wijen mempunyai kandungan kalsium yang tinggi sehingga dapat meningkatkan kandungan kalsium susu kedelai. Tujuan penelitian ini adalah untuk mengetahui pengaruh perbandingan kedelai dengan wijen sangrai giling terhadap kadar kalsium susu kedelai. Metode penelitian menggunakan rancangan acak lengkap dengan 3 taraf perlakuan, perbandingan kedelai dengan wijen sangrai giling adalah 100\%: 0\% (kontrol), $85 \%: 15 \%$ dan $70 \%$ : 30\%. Penentuan kadar kalsium menggunakan metode AAS. Data dianalisa dengan uji Anova, dilanjutkan dengan uji Duncan. Hasil dari penelitian ini adalah kadar kalsium yang optimal terdapat pada perlakuan susu kedelai dari perbandingan kedelai dengan wijen sangrai giling, 85\% : 15\%. Kesimpulan penelitian ini adalah terdapat pengaruh perbandingan kedelai dengan wijen sangrai giling terhadap kadar kalsium.
\end{abstract}

Kata Kunci: Susu Kedelai, Perbandingan Bahan, Wijen Sangrai Giling, Kadar Kalsium.

Abstract. Calcium deficiency in adolescence and early adulthood will increase the risk of osteoporosis. The prevalence of osteoporosis in Indonesian people in 2005 was $10.3 \%$, the prevalence of osteopenia in the young (age $<25$ years) was $37.1 \%$ and in young adult women (aged $18-23$ years) reached $39.5 \%$. One way to prevent osteopenia and osteoporosis is to consume cow's milk. The problem is that cow's milk is expensive, so possible alternative to solve the problem is consume soybean milk. However, soybean milk has an unpleasant taste and odor as well as lower calcium content than cow's milk. On the other side, sesame has a high calcium content, so it might increase the calcium level of soybean milk. The purpose of the study was to evaluate the effect of variation of the ratio of soybean and milled roasted-sesame on the calcium content. A completely randomized design with 3 treatments, comparison soybean and milled roasted-sesame were 100\%:0\% (control), 85\%:15\% and 70\%: 30\%. The calcium content was measured using AAS. Data were analyzed using Anova, followed by Duncan at a level 0,05. The optimal of 
calcium contentwas displayed by 85\%:15\%, was 54,03 ppm. There was an effect of different ratio of mixture of soybean and milled roasted-sesame on the calcium content.

Keywords: soybean milk, comparison of materials, milled roasted-Sesame, calcium content.

\section{PENDAHULUAN}

Kalsium bersama-sama fosfor merupakan mineral utama penyusun tulang. Kebutuhan kalsium selama remaja akan meningkat sejalan dengan berlangsungnya proses pertumbuhan tulang. Mann dan Truswell (2002), menyatakan bahwa remaja menjelang usia 20 tahun akan mengalami pembentukan tulang yang pesat, hal ini merupakan masa persiapan untuk mencapai puncak pertumbuhan massa tulang (peak bone mass). Peak bone mass dan pembentukan tulang selama remaja akan menentukan densitas tulang seseorang dimasa dewasa. Densitas tulang inilah yang berkaitan dengan status osteopenia dan osteoporosis.

Spear (2004), menyatakan bahwa risiko osteoporosis akan meningkat apabila terjadi kekurangan kalsium di masa remaja dan dewasa awal. Osteoporosis merupakan penyakit tulang yang ditandai dengan rendahnya masa tulang, yang diantaranya disebabkan karena kalsium dan elemen dari tulang berkurang secara abnormal sehingga tulang menjadi rapuh, keropos dan mudah patah (Wijayakusuma, 2011).

Prevalensi osteoporosis penduduk Indonesia tahun 2005 adalah 10,3\% dan penderita osteopenia atau penurunan massa tulang dini mencapai 41,7\% (Pusat Penelitian dan Pengembangan Gizi dan Makanan Depkes RI dan PT Fonterra Brands, 2005). Rachmawati (2006), menyatakan bahwa osteopenia juga menyerang kaum muda yang berumur kurang dari 25 tahun dengan prevalensi 37,1\%.

Berdasarkan penelitian Hermastuti dan Isnawati (2012), diketahui bahwa 39,5\% wanita dewasa muda umur 18 - 23 tahun mengalami osteopenia. Adapun penelitian Hardinsyah, Damayanthi dan Zulianti (2008), menunjukkan adanya kecenderungan bahwa siswa yang mengalami defisiensi kalsium juga mempunyai densitas tulang yang rendah.

Salah satu cara untuk mencegah terjadinya osteoponia dan osteoporosis adalah dengan mengkonsumsi makanan yang tinggi kandungan kalsiumnya, misalnya susu sapi. Permasalahannya susu sapi ini harganya relatif mahal sehingga tidak terjangkau untuk semua kalangan masyarakat. Salah satu alternatifnya adalah dengan mengkonsumsi susu kedelai (Koswara, 2006).

Kualitas protein susu kedelai hampir sama dengan kualitas protein susu sapi (Koswara, 2006). Selain itu susu kedelai tidak mengandung laktosa sehingga susu ini cocok dikonsumsi penderita intoleransi laktosa, yaitu seseorang yang tidak mempunyai enzim laktase dalam tubuhnya (Cahyadi, 2007). Masalah intoleransi laktosa merupakan alasan dari $9,1 \%$ remaja perempuan untuk tidak minum susu (Hardinsyah, Damayanthi dan Zulianti, 2008). Wahyuningsih (2010), menyatakan bahwa susu kedelai merupakan susu pengganti bagi orang-orang yang alergi terhadap susu sapi namun demikian susu kedelai juga mempunyai beberapa kelemahan.

Salah satu kelemahan susu kedelai adalah rasa dan baunya langu. Koswara (2006), menyatakan bahwa rasa dan bau langu susu kedelai disebabkan karena adanya enzim lipoksigenase yang terdapat pada kedelai. Kelemahan susu kedelai yang lain adalah kandungan kalsiumnya lebih rendah dari susu sapi, yaitu hanya sekitar $1 / 3$ susu sapi (Atmarita, 2005). Astawan (2009), menyatakan bahwa tepung wijen sering digunakan sebagai sumber kalsium alternatif bagi orang yang alergi susu sapi. Hal ini disebabkan karena 
wijen mengandung kalsium yang tinggi. Kandungan kalsium wijen per 100 gram adalah $1125 \mathrm{mg}$ (Atmarita, 2005), sedangkan dari penelitian Siong, Choo dan Shahid (1989) diketahui bahwa kadar kalsium wijen adalah 55,3 mg.Hal inilah yang menyebabkan penambahan wijen sangrai giling pada susu kedelai akan meningkatkan kandungan kalsium susu kedelai.

Berdasarkan latar belakang masalah, penulis tertarik untuk meneliti tentang pengaruh perbandingan kedelai dengan wijen sangrai giling terhadap kadar kalsium susu kedelai.

Tujuan penelitian ini adalah untuk mengetahui pengaruh perbandingan kedelai dengan wijen sangrai giling terhadap kadar kalsium susu kedelai.

\section{METODE PENELITIAN}

Jenis penelitian ini adalah eksperimen yang bertujuan untuk mengetahui perbedaan kadar kalsium susu kedelai yang dibuat dari perbandingan kedelai dengan wijen sangrai giling dalam jumlah tertentu.

Penelitian ini dilakukan di Laboratorium Ilmu Teknologi Pangan (ITP) Program Studi Gizi Fakultas Ilmu Kesehatan Universitas Muhammadiyah Surakarta, untuk pembuatan wijen sangrai giling dan susu kedelai. Pengujian kadar kalsium susu kedelai dengan metode AAS dilakukan di laboratorium Kimia dan Kesuburan Tanah Fakultas Pertanian Universitas Sebelas Maret Surakarta.

Penelitian pendahuluan dilakukan pada bulan Januari tahun 2013,. sedangkan penelitian utama dilaksanakan pada bulan Januari sampai Juli 2013.

Rancangan penelitian yang digunakan adalah rancangan acak lengkap (RAL) dengan tiga macam perlakuan dan tiga kali ulangan, Perbandingan kedelai dengan wijen sangrai giling yang digunakan adalah 100\%: $0 \%$, $85 \%: 15 \%$ dan $75 \%: 30 \%$.

Variabel penelitian ini meliputi : variabel bebas (perbandingan kedelai dengan wijen sangrai giling), variabel terikat (kadar kalsium dan daya terima susu kedelai).
Bahan pembuatan susu kedelai adalah kedelai kuning yang diperoleh dari pasar tradisional Desa Bono, Tulung, Klaten, wijen putih kualitas II yang diperoleh dari pasar Gabus, Jatinom, Klaten, gula pasir dan garam. Bahan untuk analisa kadar kalsium adalah susu kedelai (masing -masing $10 \mathrm{ml}$ untuk satu sampel), gas neon atau argon, larutan standar $\mathrm{Ca}^{2+}$, asam nitrat pekat $\left(\mathrm{HNO}_{3}\right)$ dan asam perkhlorat $\left(\mathrm{HClO}_{4}\right)$ dan bahan untuk uji daya terima adalah tiga sampel susu kedelai sesuai perlakuan.

Peralatan yang digunakan untuk Alat pembuatan wijen sangrai giling adalah wajan tanah, irus dan blender.peralatan untuk pembuatan susu kedelai dalahpanci, oven yang dapat diatur suhu dan waktu penggunaan, pengaduk/ irus, timbangan, blender, kain saring, termometer, arloji, corong dan kompor. Peralatan untuk analisa kadar kalsium dengan metode AAS, alat AAS (merk SHIMADZU, type AA-6200), waterbath, tabung reaksi, rak tabung, gelas ukur, pipet volum, pipet filter, pipet tetes dan batang pengaduk, dan peralatan untuk uji daya terima adalah gelas dan sendok.

Prosedur penelitian meliputi penelitian pendahuluan dan penelitian utama. Tujuan penelitian pendahuluan adalah untuk optimalisasi proses dan mutu susu kedelai. Optimalisasi proses terdiri dari penelitian untuk pembuatan wijen sangrai giling dan pengujian kadar kalsium, sedangkan optimalisasi mutu susu kedelai adalah dengan uji sensoris kekentalan susu kedelai.

Pada awalnya wijen yang digunakan akan dibuat menjadi tepung, namun pada uji pendahuluan ternyata wijen yang telah disangrai tidak dapat langsung dibuat tepung. Hal ini karena apabila semakin lama wijen sangrai digiling, maka akan semakin menggumpal, sehingga tidak dapat diayak menjadi tepung.

Pembuatan wijen sangrai giling adalah menurut Haryoto (2008), dengan modifikasi pada lama penyangraian dan adanya penggilingan pada wijen sangrai. Adapun diagram alir pembuatan wijen sangrai giling dapat dilihat pada Gambar 1. 


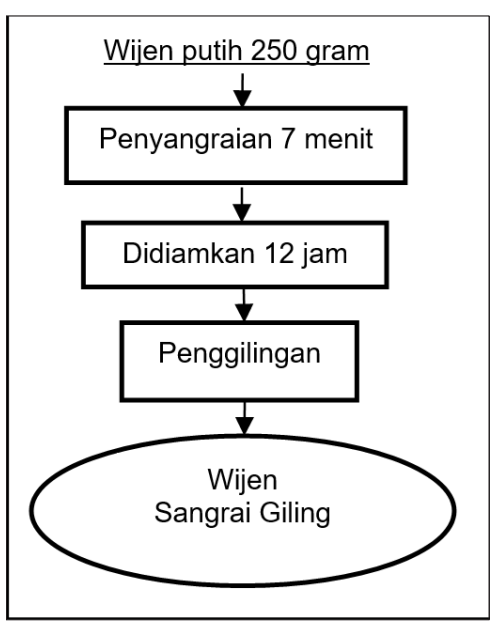

Gambar 1. Diagram Alir Pembuatan Wijen Sangrai Giling (Haryoto, 2008)

Keterangan :

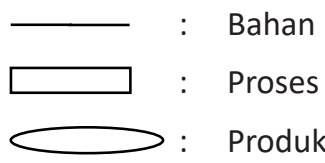

Pembuatan Susu Kedelai adalah menurut Esti dan Sediadi (2000), dengan modifikasi pada proses perebusan kedelai menjadi pengukusan kedelai.

Adapun langkah-langkah pembuatan susu kedelai adalah sebagai berikut:

1. Kedelai dibersihkan dari segala kotoran.

Berat kedelai disesuaikan dengan perlakuan.

2. Kedelai direndam dalam air selama 12 jam. Perbandingan kedelai dengan air adalah $1: 3$.

3. Kedelai dikupas kulit arinya

4. Kedelai dikukus selama 10 menit (pada kondisi air mendidih)

5. Kedelai dicampur dengan wijen sangrai giling dan air dengan suhu $80^{\circ} \mathrm{C}$, yang diukur dengan termometer.Perbandingan bahan dan air panas adalah 1:9, kemudian digiling hingga menjadi bubur.Berat wijen sangrai giling disesuaikan dengan perlakuan.

6. Bubur kedelai disaring dengan kain saring sehingga diperoleh susu kedelai.

7. Susu kedelai dimasak kemudian ditambah gula dan garam. Susu dimasak sampai mendidih dan ditunggu selama 15 menit dalam kondisi mendidih.
8. Susu kedelai kemudian dipasteurisasi pada suhu $90^{\circ} \mathrm{C}$ selama 15 menit.

Pengolahan data penelitian dengan menggunakan software SPSS versi 16. Data kadarkalsium dan daya terima dianalisa dengan uji One way anova. Data yang dilanjutkan dengan uji Duncan adalah data kadar kalsium dan daya terima terhadap kekentalan.

\section{HASIL PENELITIAN}

\section{Gambaran Umum Obyek Penelitian}

Susu kedelai pada penelitian ini adalah susu kedelai yang terbuat dari perbandingan kedelai dengan wijen sangrai giling. Fungsi wijen sangrai giling disiniadalah untuk meningkatkan kandungan kalsium susu kedelai.

\section{Hasil Penelitian Pendahuluan}

Penentuan kadar kalsium dengan metode Atomic Absorption Spectrophotometric (AAS). Hasil penelitian pendahuluan tentang kadar kalsium dengan metode AAS, diketahui bahwa kadar kalsium susu kedelai yang paling optimal adalah susu kedelai dari perbandingan kedelai dengan wijen sangrai giling, $80 \%$ : $20 \%$. Hasil penelitian pendahuluan tentang kadar kalsium yang lebih lengkap dapat dilihat pada Tabel 1.

Tabel 1

Kadar Kalsium Susu Kedelai dengan Wijen Sangrai Giling pada Penelitian Pendahuluan

\begin{tabular}{ll}
\hline $\begin{array}{c}\text { Persentase } \\
\text { Perbandingan kedelai : } \\
\text { wijen sangrai giling }\end{array}$ & $\begin{array}{c}\text { Rata-rata Kadar } \\
\text { Kalsium } \pm \text { SD } \\
(\mathbf{p p m})\end{array}$ \\
\hline $100 \%: 0 \%$ (kontrol) & $29,38 \pm 1,65^{\mathrm{a}}$ \\
$90 \%: 10 \%$ & $49,01 \pm 2,40^{\mathrm{b}}$ \\
$80 \%: 20 \%$ & $52,90 \pm 2,04^{\mathrm{c}}$ \\
Nilai sig (p) & 0,000 \\
\hline
\end{tabular}

*Notasi pada kolom yang berbeda menunjukan perbedaan yang signifikan

Tabel 1 menjelaskan bahwa masingmasing perlakuan menghasilkan kadar kalsium yang berbeda. Berdasarkan analisis statistikAnova pada tingkat kepercayaan 
95\% menunjukkan bahwa penggunaan wijen sangrai giling memberikan pengaruh yang signifikan terhadap kadar kalsium susu kedelai $(\mathrm{p}=0,000)$. Berdasarkan analisis statistik Duncanpada tingkat kepercayaan 95\% menunjukkan bahwa kadar kalsium masing masing perlakuan berbeda secara signifikan.

Susu kedelai dengan perbandingan kedelai : wijen sangrai giling, 80\% : 20\%, mempunyai kadar kalsium yang paling tinggi, yaitu 52,90 ppm, sehingga pada uji sensoris dilakukan penelitian dengan perbandingan kedelai : wijen sangrai giling, 100\%: $0 \%$ (kontol), 80\% : 20\% dan 60\% : 40\%.

Uji sensoris yang dilakukan adalah uji sensoris terhadap kekentalan susu kedelai. Berdasarkan uji sensoris yang dilakukan ternyata susu kedelai yang terbuat dari perbandingan kedelai dengan wijen sangrai giling, 60\% : 40\% tidak layak disebut sebagai susu karena menyerupai bubur encer, sehingga untuk penelitian utama susu kedelai yang diteliti kadar kalsium dan daya terima adalah susu kedelai yang terbuat dari perbandingan kedelai dengan wijen sangrai giling, $100 \%$ : 0\%, 85\% : $15 \%$ dan $70 \%: 30 \%$.

Pada penelitian ini tidak dibuat susu kedelai dari perbandingan kedelai dengan wijen sangrai giling, 55\%:45\% karena dengan perbandingan $60 \%$ : $40 \%$, sudah diperoleh susu kedelai yang menyerupai bubur encer.

\section{HASIL PENELITIAN UTAMA}

\section{Kadar Kalsium}

Rata-rata kadar kalsium pada penelitian Utama dapat dilihat pada Tabel 2. Tabel 2 menunjukkan bahwa susu kedelai yang terbuat dari perbandingan kedelai : wijen sangai giling, $85 \%: 15 \%$ dan $70 \%: 30 \%$ mempunyai kadar kalsium yang berbeda nyata dengan susu kedelai kontrol $(\mathrm{p}=0,006)$. Kandungan kalsium yang tinggi pada wijen inilah yang menyebabkan kadar kalsium susu kedelai yang terbuat dari perbandingan kedelai : wijen sangai giling, $85 \%$ : $15 \%$ dan $70 \%: 30 \%$ menjadi lebih tinggi.
Tabel 2

Kadar Kalsium Susu Kedelai dengan Wijen Sangrai Giling pada

Penelitian Utama

\begin{tabular}{cc}
\hline $\begin{array}{c}\text { Persentase } \\
\text { Perbandingan } \\
\text { kedelai : wijen } \\
\text { sangrai giling }\end{array}$ & $\begin{array}{c}\text { Rata-rata Kadar } \\
\text { Kalsium } \pm \text { SD } \\
(\mathbf{p p m})\end{array}$ \\
\hline $100 \%: 0 \%$ (kontrol)) & $29,18 \pm 1,62^{\mathrm{a}}$ \\
$85 \%: 15 \%$ & $54,03 \pm 7,17^{\mathrm{b}}$ \\
$70 \%: 30 \%$ & $52,56 \pm 8,74^{\mathrm{b}}$ \\
Nilai Sig (p) & 0,006 \\
\hline
\end{tabular}

*Notasi pada kolom yang berbeda menunjukan perbedaan yang signifikan

Tabel 2 menunjukkan bahwa susu kedelai yang terbuat dari perbandingan kedelai : wijen sangai giling, $85 \%$ : $15 \%$ dan $70 \%$ : $30 \%$ mempunyai kadar kalsium yang berbeda nyata dengan susu kedelai kontrol $(\mathrm{p}=0,006)$. Kandungan kalsium yang tinggi pada wijen inilah yang menyebabkan kadar kalsium susu kedelai yang terbuat dari perbandingan kedelai : wijen sangai giling, $85 \%: 15 \%$ dan $70 \%: 30 \%$ menjadi lebih tinggi.

Adapun pengaruh perbandingan kedelai dengan wijen sangrai giling terhadap kadar kalsium susu kedelai disajikan pada Gambar 2.

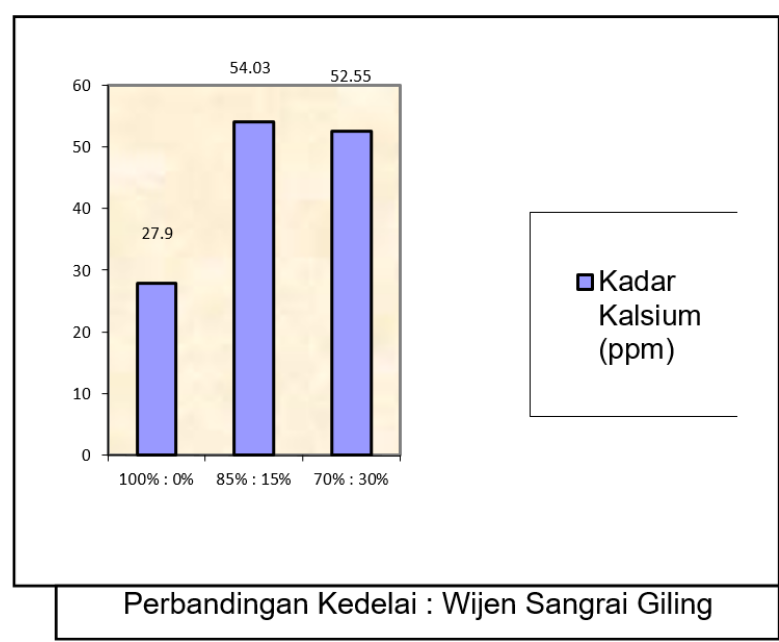

Gambar 2. Kadar Kalsium Susu Kedelai

Berdasarkan Gambar 7, diketahui bahwa hasil rata - rata kadar kalsium susu kedelai kontrol memiliki kadar kalsium paling rendah yaitu sebesar 29,18 ppmsedangkan kadar 
kalsium tertinggi terdapat pada susu kedelai yang terbuat dari perbandingan kedelai : wijen sangai giling, $85 \%$ : $15 \%$ yaitu sebesar 54,03 ppm.

Hasil penelitian ini menunjukkan bahwa penggunaan wijen sangrai pada pembuatan susu kedelai dapat dijadikan sebagai alternatif minuman yang kaya kalsium, mencegah osteopenia dan osteoporosis serta sebagai alternatif minuman bagi remaja yang intoleransi laktosa.

\section{KESIMPULAN DAN SARAN}

\section{Kesimpulan}

Kadar kalsium paling tinggi terdapat pada susu kedelai yang terbuat dari kedelai : wijen sangrai giling, $85 \%: 15 \%$, yaitu sebanyak $54,03 \mathrm{ppm}$

\section{Saran}

Penggunaan wijen sangrai giling kurang efektif karena bahan ini digiling bersama kedelai kemudian disaring menjadi susu mentah, sehingga memungkinkan kandungan kalsium ikut terbuang bersama ampas ketika penyaringan. Perlu dilakukan penelitian lebih lanjut mengenai pembuatan tepung wijen sangrai, karena dalam bentuk tepung, tepung tersebut ditambahkan pada saat sudah menjadi susu mentah, sehingga lebih efektif.

\section{DAFTAR PUSTAKA}

Astawan, M. 2009. Sehat dengan Hidangan Kacang dan Biji-bijian. Penebar Swadaya. Jakarta. Atmarita (ed.). 2005. Daftar Komposisi Bahan Makanan (DKBM). Persagi Indonesia. Jakarta.

Cahyadi, W., 2007.Teknologi dan Khasiat Kedelai, Bumi Aksara, Jakarta

Esti dan Sediadi (ed.). 2000. Susu Kedelai. Kantor Deputi Menegristek Bidang Pendayagunaan dan Pemasyarakatan Ilmu Pengetahuan dan Teknologi.Diakses 15 Februari 2012.http:// ww.warintek.ristek.go.id

Hardinsyah, Damanyanthi, E. dan Zulianti, W., 2008. Hubungan Konsumsi Susu dan Kalsium dengan Densitas Tulang dan Tinggi Badan Remaja.Jurnal Gizi dan Pangan. 3 (1) : 43 - 48.

Haryoto. 2008. Susu dan Yoghurt Kecipir. Edisi ke-7.Kanisius.Yogyakarta.

Koswara, S. 2006. Susu Kedelai Tak Kalah dengan Susu Sapi. Diakses: 15 Februari 2012. http://www.ebookpangan.com.

Mann, J. dan Truswell, A, S. 2002.Essentials of Human Nutrition.Oxfod University Press. New York.

Pusat Penelitian dan Pengembangan Gizi dan Makanan Depkes RI dan PT Fonterra Bands Indonesia.2005. PrevalensiOsteopoosis dan Osteopenia. Bogor.

Rachmawati, E. 2006.Saat Pencuri Tulang Mengintai. Diakses: 23 Maret 2013.http://kompas. com/ver1/kesehatan/0609/15.

Spear, B, A. 2004.Nutrition in Adolescence.dalam Mahan, K dan Stump, S, E (Eds). Food, Nutrition and Diet Therapy.11th ed. Saunders, Pennsylvania.hlm : 284-301

Wijayakusuma, H., 2011. Mencegah Osteoporosis dengan Pola Hidup Sehat. Diakses: 21Juli 2013. http://www.itokindo.org 